\title{
Party Rhetoric and Action Compared: Examining Politicisation and Compliance in the Field of Asylum and Migration Policy in the Czech Republic and Hungary
}

\author{
Paula Beger
}

\section{l INTRODUCTION}

Since the 1990s, asylum and migration policy has been a low salience issue in East Central Europe (ECE), being barely addressed in public debates and excluded from political parties' manifestos. Until a few years ago, policies were in line with EU standards and mainly remained in the hands of the administration. With the European refugee crisis in 2015, however, the policy field all of a sudden became politicised and several governments rejected the implementation of the EU relocation scheme.

Focusing on Hungary and the Czech Republic in the period from 2015 to 2018 , this chapter investigates the link between politicisation and compliance. It starts by showing how asylum and migration policy

P. Beger $(\bowtie)$

Leipzig University, Leipzig, Germany

e-mail: paula.beger@uni-leipzig.de

(C) The Author(s) 2021

A. Lorenz and L. H. Anders (eds.), Illiberal Trends and Anti-EU Politics

in East Central Europe, Palgrave Studies in European Union Politics, https://doi.org/10.1007/978-3-030-54674-8_6 
became politicised within recent years. It then goes on to examine compliance with EU directives in the field of asylum and migration policy. It will be demonstrated that the politicisation of the policy field did not lead to general non-compliance. While governments of both countries politicised asylum and migration issues and decided not to implement the relocation scheme, the Czech Republic implemented other asylum- and migration-related EU directives. Hungary, however, also violated other EU rules in the field. Based on the compliance literature of ECE and building on expert interviews, ${ }^{1}$ it will be suggested that this is mainly due to the varying degree of politicisation of the administration. If it remains de-politicised, it executes the policy in accordance with the EU standards.

The chapter is anchored on the theoretical background of politicisation, Europeanisation and compliance research. As very little research has so far been undertaken to combine questions of politicisation and compliance with EU law, this study contributes to an under-researched area. Its empirical findings have important implications for research on illiberal trends and anti-EU politics. They suggest that the pursuit of illiberal as well as anti-EU agendas of ruling parties (for party agendas, see Chapters 5 and 7) can be counterbalanced or at least decelerated by depoliticised state bureaucracies. Future research, therefore, should focus on the administration in backsliding states and examine how governments try to capture them.

\section{The Politicisation of Asylum and Migration Policy in the Czech Republic and Hungary}

Politicisation means that the wider public sphere is involved with a specific issue. Most scholars analyse politicisation by looking at three aspects: the public salience of an issue, the number of actors involved and the polarisation of their opinions (De Wilde 2011; Rauh and Zürn 2014, p. 125). As political parties play a crucial role in this process, they are suitable research subjects when examining politicisation (Hooghe and Marks 2012; Dolezal et al. 2016, for the analysis of ECE parties, see also Chapters 5 and 7). Therefore, this section analyses party manifestos of the

\footnotetext{
${ }^{1}$ The expert interviews were conducted in 2016 and 2017 with academics and representatives from relevant think tanks as well as administrative employees of the Czech and Hungarian Ministry of Interior and the Immigration and Asylum Office in Hungary.
} 
Czech and Hungarian governing parties and the three biggest opposition parties. Manifestos are in general a valid source to identify parties' opinions (Grande and Hutter 2016, pp. 26-27) and to examine politicisation in the partisan arena. The following paragraphs also consider the public debates on asylum and migration.

In both Hungary and the Czech Republic, the policy field of asylum and migration policy ${ }^{2}$ was developed almost from scratch in the preaccession phase. In that time, the issue was not politicised. It was low in public salience and only a few parties formulated programmatic preferences (Beger 2020). The asylum and migration policy was shaped almost exclusively by the government and the responsible administration without receiving much public attention. For these actors, the EU conditionality served as the main guideline as one acquis chapter demanded the building of, for example, a proper border control, domestic institutions for law enforcement and a legislative framework for asylum and migration (European Commission 2019). The ECE governments still lacked experience with immigration and international refugee movements (Grabbe 2003, p. 306; Lavenex 1998, p. 138; Miciukiewicz 2011, p. 186), and the EU standards were adopted in a technical and uncontested downloading process (Author's interviews, Prague, 23rd January 2018; 31st January 2018; 29th January 2018; 1st February 2018).

Several of the interviewed experts confirmed that the very apolitical and bureaucratic policy field reached only the top of the political agenda with the refugee crisis $^{3}$ in the Czech Republic (Author's interviews, Prague, 23rd January 2018; 31st January 2018; 29th January 2018; 1st February 2018). Similarly, in Hungary, asylum and migration was not a disputed issue before 2015 and only since that year became prioritised

\footnotetext{
${ }^{2}$ The definition of asylum and migration policy is derived from the corresponding research in political science that addresses different sub-policies like asylum policy and policies of migration, such as labour migration or integration (Bendel 2011, p. 377; Faist and Ette 2007, p. 15). The difficulty in differentiating migration and asylum policy while respecting the interacting aspects of both categories has remained a challenge (Crisp 2010, p. 133). Consequently, this chapter frames the policy field as asylum and migration policy.

${ }^{3}$ The wording "refugee crisis" might be put into an inhuman interpretative framework. Different frames like the "Schengen crisis" (Börzel and Risse 2018) or the "external relations crisis" (Falkner 2016) seem more appropriate in this regard. However, the emphasis on the policy field of asylum and migration is at the centre of this research, and thus, the expression "refugee crisis" is chosen.
} 
(Author's interviews, Budapest, 2nd November 2017; 9th November 2017).

In Czech Parliament, the opposition parties did not delineate from the government line, even though their deputies did not have to follow any party discipline because they did not articulate their positions regarding the policy field in manifestos or party programmes (Shevel 2011, p. 224). Parties paid more attention to asylum and migration issues in the 2000s when the asylum and refugee legislation was repeatedly amended, but nevertheless abstained from formulating clear party positions. The same was true for Hungary; asylum and migration was not a widely disputed issue here either (Author's interviews, Budapest, 2nd November 2017; 9th November 2017). Thus, in both countries, the policy field remained technocratic until many years after the accession.

As mentioned, political actors started to politicise the issue only in 2015. In this year, the European refugee crisis increased the salience of asylum- and migration-related questions. The policy entered mass politics in the Czech Republic and Hungary. Though the numbers of asylum applicants in the Czech Republic were low, political parties sparked a public debate about migration and asylum. All political parties of the Czech Parliament took a restrictive stance in that matter (Jelínková 2019, p. 36f.). As experts reported, the political parties in Czechia discovered how they could direct attention towards the issue and how to exploit it electorally (Author's interview, Prague, 23rd January 2018).

In their public statements, the populist centrist Action of Dissatisfied Citizens ANO 2011 focused mainly on security issues, whereas the Social Democrats and the Christian and Democratic Union-Czechoslovak People's Party also raised the issue, but within a securitised frame. In addition, both the government and the opposition took a negative stance towards the EU migration and asylum policy in most of the press interviews concerning this policy field (Jelínková 2019, p. 39). Furthermore, many xenophobic and populist splinter parties emerged in the Czech Republic focusing on asylum and migration issues (Bertelsmann Stiftung 2018a, p. 35; for anti-Muslim attitudes, see also Chapter 3).

In the 2017 election year, when national parties were running for the election of the Chamber of Deputies, both government and opposition parties explicitly addressed the issue in their manifestos. Polarisation increased as the parties articulated more diverging positions towards the policy field of asylum and migration. In its party manifesto, ANO 2011 devoted much more attention to questions of migration than other Czech 
political parties. It declared illegal migration as the main issue in Europe and demanded to end migration waves by means of EU and NATO operations or with the help of the Czech army. Furthermore, ANO 2011 suggested punishing the abuse of the domestic asylum system with threatening penalties. The EU relocation scheme, though, was not explicitly addressed (Burst et al. 2020: ANO 2011, position 321-670). In contrast, its social democratic coalition partner CSSD openly rejected the mandatory quotas of the EU relocation scheme in its party manifesto of 2017 and opted for a preventive system to stop irregular migration while delivering development aid to African and Asian countries (Burst et al. 2020: Czech Social Democratic Party, position 446-457).

The three biggest opposition parties positioned themselves with rather short statements in their manifestos. The liberal-conservative Civic Democratic Party (ODS) demanded a consistent immigration policy that should, inter alia, set stricter conditions for the abuse of the social system (Burst et al. 2020: Civic Democratic Party, position 174-177). The Czech Pirate Party remained vague and referred to a rational approach to solve the refugee crisis. It also aimed at supporting humanitarian aid close to conflict zones (Burst et al. 2020: Czech Pirate Party, position 453-455). The populist Party Freedom and Direct Democracy (SPD) referred to the EU relocation scheme in a xenophobic manner as a forced mechanism to integrate illegal immigrants (Burst et al. 2020: Freedom and Direct Democracy, position 28-30).

In sum, while the polarisation increased when compared to the 2014 election year, in 2017, only the ČSSD and the populist SPD made an explicit reference to the EU relocation mechanism which they refused. The emerging intra- and inter-party competition over the adoption of the refugee quotas (Bertelsmann Stiftung 2018a, p. 35) was even more apparent in public debates than in the party manifestos.

In Hungary, asylum and migration has become a similarly salient topic since 2015 , although the debate took different shapes. In the run-up to the 2014 parliamentary elections, no party had even mentioned immigration in its manifesto (Manifesto Project Data Dashboard). ${ }^{4}$ Following

\footnotetext{
${ }^{4}$ Some statements can only be found in the manifesto of Fidesz from 2007. Interestingly, Fidesz supports a common European immigration policy (Fidesz 2007, p. 4lf.).
} 
the vastly increased inflow of refugees and asylum seekers in Hungary, ${ }^{5}$ the policy field was shifted from a bureaucratic management sphere to a political one, though not all political parties were increasingly involved with the issue. From 2015 onwards, political debates about asylum and migration were dominated by the governing party, the Federation of Young Democrats-Hungarian Civic Union (Fidesz). The alliance between the right-wing populist Fidesz and the conservative Christian Democratic People's Party (KDNP) started a governmental campaign against migrants. It built its public communication on mass media measures and set up a huge billboard campaign and a national consultation on immigration (Nagy 2019, p. 123). While the public discourse of the government increasingly turned to spread a "moral panic" (Barlai and Sik 2017), the government's campaign remained unchallenged by the opposition parties of the Hungarian Parliament (Nagy 2019, p. 115). Furthermore, opportunities for public criticism were restricted, as non-governmental actors were practically prohibited from broadcasting political advertisements on public TV or radio (Bertelsmann Stiftung 2018b, p. 8). The two biggest opposition parties, the right-wing extremist party Movement for a Better Hungary (Jobbik) and the Hungarian Socialist Party (MSZP), passed their manifestos right before the Parliament's elections in 2018 but did not formulate clear goals for a domestic asylum and refugee policy. Jobbik associated migration policy with the defence of the Hungarian nation and identity (Jobbik 2018), while the MSZP put the topic in a domestic context and mainly addressed Hungarian migrants (MSZP 2018).

The governing party Fidesz chose the EU relocation scheme as an issue to mobilise domestic support against the EU. First, in September 2015, the party initiated a parliamentary resolution against the EU quota system that was perceived to be encouraging immigrants to migrate to Europe (Resolution 36/2015 [IX. 22], Magyar Közlöny No. 136). Furthermore, the Hungarian government initiated a referendum in October 2016 and Hungarian citizens could vote whether the Hungarian government should comply with the relocation scheme, ${ }^{6}$ but the referendum

${ }^{5}$ As 177,000 asylum applications in total were registered in Hungary in 2015. That was an increase of $314 \%$ compared to the previous year (Statistics of the Hungarian Immigration and Asylum Office).

${ }^{6}$ The referendum was accompanied by mass media measures based on very suggestive statements while interlinking migration and asylum with terrorism and misusing the terms migration and asylum. The referendum-which posed the single question "Do you want 
was invalid due to insufficient turnout (Halmai 2016). While Fidesz became increasingly active in politicising the policy field, it surprisingly did not reflect its "intense anti-migration campaign" (Bertelsmann Stiftung 2018 b, p. 36) within its party manifesto. It rather used measures like the referendum and a parliamentary resolution to launch an EU anti-rhetoric.

In the same way, the main opposition parties only briefly described their position towards asylum and migration in their manifestos before the 2018 parliamentary elections. They appeared to be reluctant to counterbalance the public mobilisation against the EU and especially the EU relocation scheme.

Focusing on the salience, the actor expansion and the polarisation, it could be shown that the programmatic dispute was missing in both countries, as actors - if they positioned themselves-predominantly demanded restrictive asylum and migration policies. Nevertheless, the issues of migration and asylum gained high public attention in the two ECE countries.

\section{Different Degrees of Non-compliance in the Czech Republic and Hungary}

The following section analyses whether politicisation resulted in increasing non-compliance. Though it has been suggested that anti-EU rhetoric can stir non-compliant behaviour and thus lead to a disintegrative course (Börzel and Risse 2018, p. 7), the two approaches are rather used separately. In this context, ECE countries are mentioned in politicisation (Börzel and Risse 2018; Hutter and Kriesi 2019) or compliance studies (Falkner et al. 2004; Falkner et al. 2008; Sedelmeier 2009; Toshkov 2012).

Compliance performance can be measured by the number of infringement procedures. Though infringement data have to be interpreted with caution, they serve as the most valid source for comparing compliance in EU countries (Börzel and Sedelmeier 2017, p. 201). When the Commission starts an infringement procedure, a letter of formal notice is issued to the member state. It can be followed by a reasoned opinion, which sets out a clear deadline to solve the case of EU law violation that can

to allow the European Union to mandate the relocation of non-Hungarian citizens to Hungary without the approval of the National Assembly?"-demonstrated the anti-EU mobilisation of the Hungarian government. 
be caused by non-notification, non-transposition, late transposition or substantially incorrect transposition of a directive (Falkner et al. 2004, p. 456). A referral to the Court of Justice of the European Union finally sanctions the non-compliant behaviour. Thus, there is a qualitative difference between the different stages regarding the depth of non-compliance, and cases can be differentiated between severe and swiftly solved instances of non-compliance. While the formal notice suggests the first evidence of a non-compliant behaviour, a reasoned opinion can be regarded as a last final written warning before the sanctioning and serves as an indicator for measuring non-compliance (Börzel and Sedelmeier 2017, p. 201; Falkner et al. 2004, p. 456). If a member state reacts according to the reasoned opinion, the sanctioning can be avoided. Using reasoned opinions for measuring formal non-compliance, the two country cases of the Czech Republic and Hungary show different levels.

Within the period under consideration, the European Commission issued several formal notices to the Czech Republic that concerned directives of the policy field. In 2015, for the first time, the Commission sent two formal notices that criticised the execution of common procedures for granting and withdrawing international protection and the standards for the reception of asylum. A year later, the Commission found fault with the conditions for third-country nationals coming as seasonal workers or for the purposes of research, studies, training, voluntary service, pupil exchange schemes or educational projects and au pairing (European Commission Database on infringement cases). Though these formal notices were not followed by reasoned opinions that defined a stage of non-compliance, it is striking that the same year when the European refugee crisis became part of the public debate, the Czech Republic got their first formal notices concerning the policy field. In 2017, the Commission started an infringement procedure against the Czech Republic for not transposing the Council Decisions 2015/1523 and 2015/1601 on relocation and resettlement. As there was no indication that the Czech Republic would start relocating to its territory, the Commission referred the case to the Court of Justice of the European Union (European Commission 2017b). As demonstrated in Table 1, the refusal to implement the relocation scheme was a definite non-compliant behaviour.

Compared to the Czech Republic, Hungary has less infringement proceedings but more of them are referred to the Court of Justice of 


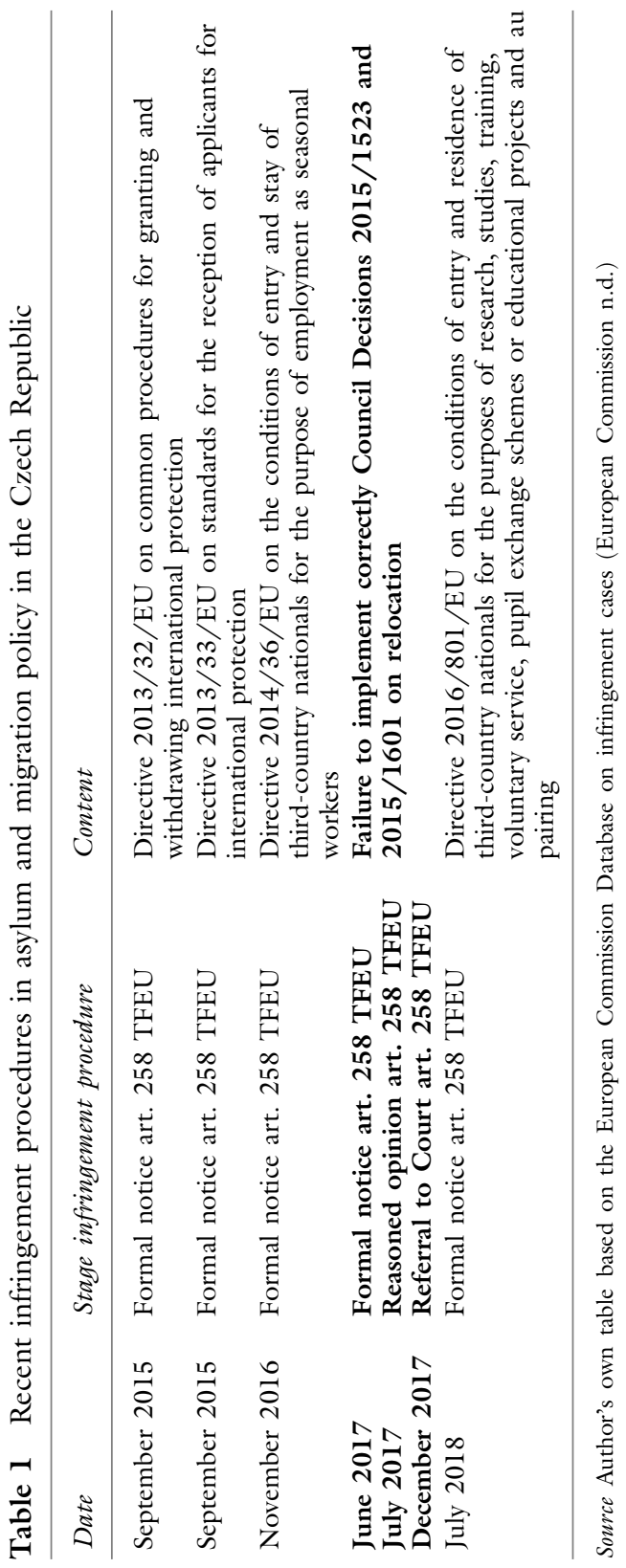


the European Union and thus indicate a more severe form of noncompliance. Contrary to the Czech case, Hungary already received formal notices concerning the policy field before 2015 (see Table 2).

In 2013, the Commission sent a formal notice on grounds of noncompliance with EU asylum directives and the EU Charter of Fundamental Rights. A year later, it criticised the standards for the qualification of third-country nationals as beneficiaries of international protection. These formal notices were not followed by reasoned opinions, indicating that the instances of non-compliance were solved swiftly. However, in 2015 , the number and scope of the infringement procedures increased remarkably. The Commission addressed Hungary in a formal notice as the country did not comply with the EU asylum and migration acquis, including several directives (Directive 2013/32/EU on Asylum Procedures, Directive 2008/115/EC on Return, on Reception Conditions) as well as several provisions of the Charter of Fundamental Rights (European Commission 2017a).

After a period of two months to respond to the Commission's reasoned opinion, the majority of the concerns raised had still not been addressed and the Commission referred the case to the Court of Justice of the European Union in 2018 (European Commission 2018). The failure to correctly implement the Council Decision 2015/1601 on relocation led to another infringement procedure that was referred to the Court of Justice of the European Union half a year later after Hungary had not taken any action at all since the relocation scheme started (European Commission 2017b). Further formal notices followed afterwards that also concerned third-country nationals for the purposes of, inter alia, research, training, exchange schemes, measures against illegal immigration and long-term residents (European Commission Database on infringement cases).

Comparing the compliance performance in the Czech Republic and Hungary in the field of asylum and migration, it can be summarised that in both countries, the infringement procedures considerably increased since 2015 when the European refugee crisis became politicised in domestic public debate. While more procedures were swiftly solved in the Czech Republic, the case of Hungary shows a more severe form of non-compliance. 


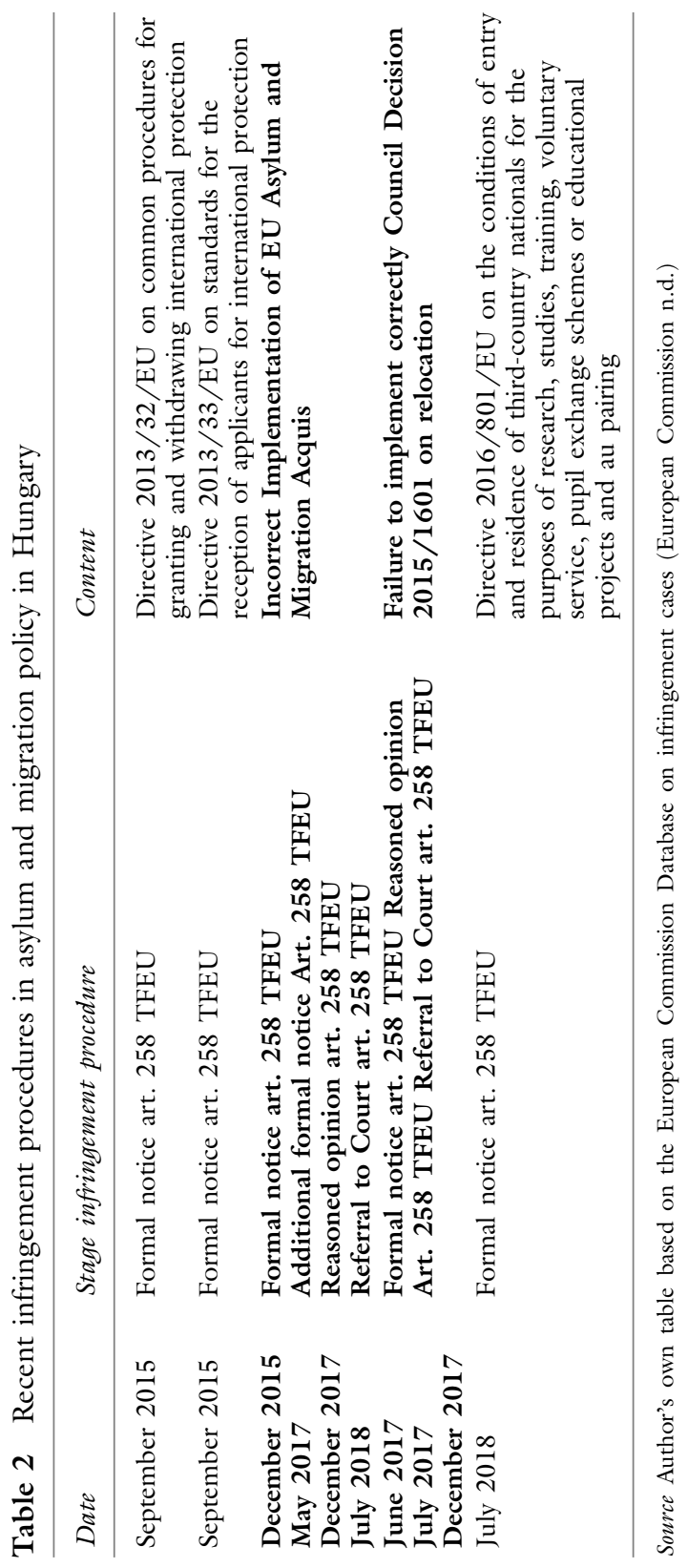




\section{Action in the Background: The De-Politicised Administration as a Missing Piece of the Puzzle}

The previous sections suggest that the compliance in the very policy field cannot solely be explained by politicisation. Comparable levels of politicisation in both countries yielded different results. As I will argue in the following, this can be explained by considering the role of the administration.

As we know from quantitative studies and comparative case studies on compliance with EU law, the ECE countries generally outperform their Western counterparts. They transpose EU legislation faster and also settle infringement procedures more rapidly (Börzel and Sedelmeier 2017, p. 197ff.; Sedelmeier 2011, p. 26; Zhelyazkova et al. 2017, p. 223f.). It has been repeatedly shown that administrative capacity serves as an explanatory factor for this good compliance performance (Börzel et al. et al. 2010; Falkner et al. 2004; Hille and Knill 2016). Especially, in the policy field under scrutiny, the administration in ECE countries had a shaping power while the policy field was developed during the EU accession phase when it efficiently implemented the strict EU conditionality. According to this line of reasoning, ECE countries with a high administrative efficiency and specialised bureaucracy achieve good compliance as they successfully passed a stress test while adopting a huge amount of legislation in quite a short period (Börzel and Sedelmeier 2017, Zhelyazkova et al. 2017, p. 231).

Part of this explanation is the idea of a technocratic, non-political administration which focuses on the efficient implementation of law. Before Eastern enlargement, the reform of the ECE countries' centralised and then over-politicised administrations (Goetz and Wollmann 2001) was part of the EU conditions for accession. By setting a de-politicised bureaucracy as a precondition for acceding the EU, the Commission sought to prevent party patronage (Meyer-Sahling 2006, p. 9). It therefore closely monitored especially the de-politicisation of the senior civil servants in order to separate politics and administration in the higher ranks below the political leadership (Meyer-Sahling 2011, p. 239f.).

Scholars expected that this strong technocratisation in the accession process could be at the expense of elected political actors in the postaccession period (Lippert et al. 2001, p. 982f.). They assumed the decoupling of the administrative execution and party politics would 
continue even after the EU accession. The costs of replacing the welltrained, de-politicised and well-connected personnel would have been too high to be replaced by-potentially less competent-party representatives: "The growing involvement of the ministerial bureaucracy in East Central European countries in EU policy, growing contacts, and increasing investment in the competence levels of officials suggests that the costs of replacing ministerial civil servants have been continuously rising rather than decreasing and that the size of politicisation-free zones in the ministerial bureaucracy is likely to grow" (Meyer-Sahling 2006, p. 25f.).

In fact, the Czech Ministry of Interior is considered an institution that was "perhaps the most thoroughly cleansed following the Velvet Revolution" (Shevel 2011, p. 196). It can be assumed that, among others, the migration and refugee policy-executing body was detached from party politics and the personnel had been exchanged before the EU accession. Experts confirmed that Czech asylum and migration has been a very apolitical field until the refugee crisis and was mainly administrative and bureaucratic (Author's interviews, Prague, 23rd January 2018). The division responsible, the Department of Asylum and Migration Policy at the Ministry of Interior, has been led by Tomáš Haišman since 1993 for about 25 years (Shevel 2011, p. 197f.). It is considered that he was the main driver and most experienced person of the domestic asylum and migration policy. (Author's interviews, Prague, 23rd January 2018)

In the Czech Republic, the new salience of the policy field provoked an enhanced public contestation of the government when the relocation scheme was announced in 2015 . According to that, the mandatory model of the relocation mechanism was considered as problematic across official bodies (Author's interviews, Prague, 23rd January 2018; 1st February 2018). In general, a compliant behaviour of the Czech government was not to be expected in that matter: "How destructive was the discussion about quotas as in our country. It destroyed the political will concerning a real contribution in the EU framework to the migration crisis" (Author's interview, Prague, 18th January 2018).

Despite the politicisation of the policy field and the salience of the EU relocation scheme, it was the policy-executing bureaucracy in its daily practice which examined and decided upon asylum applications. As various administrative employees underlined, their application of the asylum law did not change (Author's interviews, Prague, 18th January 2018; 29th January 2018). This puts the non-compliance of the Czech 
government in the case of the relocation scheme in a different light. While the relocation mechanism was used by, inter alia, party politicians to further polarise the policy field as a salient public issue, the politicisation of the policy field did not lead to non-compliance because of an efficient and de-politicised bureaucracy.

In the Hungarian case, in contrast, it seems that the governmental strategy of restructuring the state administration and its politicisation of the policy field led to non-compliance. Though during the accession period, a de-politicisation of senior civil servants has been monitored by the Commission, the first Orbán government started to re-politicise the administration in 2001. Senior civil servants were chosen due to party preferences (Meyer-Sahling 2011, p. 247). When Orbán formed a government for a second time in 2010, the political executive continued to fill posts of the central government "with politically loyal, 'reliable' civil servants" (Hajnal and Csengódi 2014, p. 49). Thus, a decade later, the party politics of the governing parties and administrative executive have been further coupled.

The government used the EU relocation scheme as "a net internal game with a far reaching effect as it will push Hungary to the laggards of the EU" (Author's interview, Budapest, 19th October 2017). While in the Czech Republic the administration in the policy field continued to operate as before, in Hungary, there appears to be a political influence on the relevant bureaucracy. As one of the interviewees from the Immigration and Asylum Office stated "Our office has to wait [...] and if in the future a positive result could come from this debate and we will participate in any way in the future relocation and resettlement programme, our office could participate in this programme $[\ldots]$ because we have the experience from our previous resettlement programmes. If the situation will be so, our office will be ready to implement" (Author's interview, Budapest, 9th November 2017). These considerations let the non-compliance in the relocation scheme appear different to the Czech case, and the rejection of the relocation mechanism points to a more structural level of noncompliance in the policy field.

\section{Conclusion}

This chapter investigated the politicisation of the asylum and migration policies since 2015 and also examined the compliance performance in Hungary and the Czech Republic. Combining expert interviews and 
findings from politicisation and compliance research, it suggests that the raising salience of an issue affecting party programmes can affect the compliance performance with EU standards, but that the level of the administration's politicisation intermediates this effect.

Empirically, the moment of the European refugee crisis and the rejection of the EU relocation scheme constituted a turning point. The formerly rather "technical" policy field that was mainly managed by the responsible administration became politicised. In the Czech Republic, some party actors actively responded to the raised issue and new parties emerged, although they would conform with the EU-critical position of the national government in this policy field. In Hungary, actors from opposition parties hardly mobilised and the issue was mainly raised by the government. However, in the Czech case, the politicisation of the policy field did not lead to a broader non-compliance, and so far, only the relocation scheme has not been adhered to. As for Hungary, non-compliance with EU law has increased.

To explain these differences, the chapter drew on studies on the accession process. They highlight that de-politicisation of the administration was a precondition to join the EU and that a de-politicised bureaucracy manages the implementation of EU law efficiently.

In the Czech Republic, this was undoubtedly the case, but in Hungary, the asylum-related administration, like other bureaucratic fields, has become increasingly re-politicised during the last decade. Since party politics of the governing parties and the administrative executive's action have been further coupled, the politicised state administration followed the government's approach of non-compliance with EU law in the policy field.

These results are of utmost importance for research on the relationship between the EU and its member states as well as domestic policy patterns. While studies of illiberal backsliding in ECE often focus on institutional reforms, administrations have received less attention. Future studies will hence need to observe their influence upon mechanisms of politicisation and compliance in greater detail (see also Chapter 14). Administrative action promises to be an important piece of the puzzle to this interrelation. 


\section{References}

Barlai, M., and E. Sik. 2017. A Hungarian trademark (a "Hungarikum"): The Moral Panic Button. In The Migrant Crisis: European Perspectives and National Discourses, ed. M. Barlai, C. Griessler, B. Fähnrich, and M. Rhomberg, 147-168. Zürich: LIT.

Beger, Paula. 2020. A Product of Europeanisation or of National Handwriting? The Formation and Development of the Czech Migration Policy. In Czech Democracy in Crisis, ed. A. Lorenz and H. Formánková. Basingstoke: Palgrave Macmillan.

Bendel, Petra. 2011. Asylum and Migration Policy. In Policies within the EU Multi-Level System. Instruments and Strategies of European Governance, ed. H. Heinelt and M. Knodt, 371-384. Baden-Baden: Nomos.

Bertelsmann Stiftung. 2018a. BTI 2018 Country Report-Czech Republic. Gütersloh: Bertelsmann Stiftung. https://www.bti-project.org/fileadmin/ files/BTI/Downloads/Reports/2018/pdf/BTI_2018_Czech_Republic.pdf. Accessed 18 October 2019.

Bertelsmann Stiftung. 2018b. BTI 2018 Country Report-Hungary. Gütersloh: Bertelsmann Stiftung. https://www.bti-project.org/fileadmin/files/ BTI/Downloads/Reports/2018/pdf/BTI_2018_Hungary.pdf Accessed 17 October 2019.

Börzel, T.A., T. Hofmann, D. Panke, and C. Sprungk. 2010. Obstinate and Inefficient. Why Member States Do Not Comply With European Law. Comparative Political Studies 43 (11): 1363-1390.

Börzel, T.A., and U. Sedelmeier. 2017. Larger and More Law Abiding? The Impact of Enlargement on Compliance in the European Union. Journal of European Public Policy 24 (2): 197-215.

Börzel, T.A., and T. Risse. 2018. From the Euro to the Schengen Crises: European Integration Theories, Politicization, and Identity Politics. Journal of European Public Policy 25 (1): 83-108.

Burst, Tobias et al. 2020. Manifesto Corpus. Version: 2020-1. Berlin: WZB Berlin Social Science Center.

Cirtautas, A.M., and F. Schimmelfennig. 2010. Europeanisation Before and After Accession: Conditionality, Legacies and Compliance. Europe-Asia Studies 62 (3): 421-441.

Crisp, Jeff. 2010. A New Asylum Paradigm. Globalization, migration, and the Uncertain Future of the International Refugee Regime. In Migration. Critical Concepts in the Social Sciences, ed. Steven Vertovec, 129-141. London and New York: Routledge.

De Wilde, Pieter. 2011. No Polity for Old Politics? A Framework for Analyzing the Politicization of European Integration. Journal of European Integration 33 (5): 559-575. 
Dimitrova, Antoaneta L. 2005. Europeanization and Civil Service Reform in Central and Eastern Europe. In The Europeanization of Central and Eastern Europe, ed. F. Schimmelfennig and U. Sedelmeier, 71-90. Ithaca: Cornell University Press.

Dolezal, M., E. Grande, and S. Hutter. 2016. Exploring Politicisation: Design and Methods. In Politicising Europe: Integration and Mass Politics, ed. S. Hutter, E. Grande, and H. Kriesi, 32-60. Cambridge: Cambridge University Press.

European Commission. n.d. Infringement Decisions. http://ec.europa.eu/atw ork/applying-eu-law/infringements-proceedings/infringement_decisions/ind ex.cfm. Accessed 27 October 2018.

European Commission. 2017a. Migration: Commission Steps Up Infringement Against Hungary Concerning Its Asylum Law. http://europa.eu/rapid/pressrelease_IP-17-5023_EN.htm. Accessed 23 November 2018.

European Commission. 2017b. Relocation: Commission Moves to Next Stage in Infringement Procedures Against the Czech Republic, Hungary and Poland. http://europa.eu/rapid/press-release_IP-17-2103_EN.htm. Accessed 23 November 2018.

European Commission. 2018. Migration and Asylum: Commission Takes Further Steps in Infringement Procedures Against Hungary. http://europa.eu/rapid/ press-release_IP-18-4522_EN.htm. Accessed 23 November 2018.

European Commission. 2019. Chapters of the Acquis. https://ec.europa.eu/nei ghbourhood-enlargement/policy/conditions-membership/chapters-of-theacquis_en. Accessed 15 November 2019.

Faist, T., and A. Ette. 2007. The Europeanization of National Policies and Politics of Immigration: Research, Questions and Concepts. In The Europeanization of National Policies and Politics of Immigration. Between Autonomy and the European Union, ed. T. Faist and A. Ette, 3-31. New York: Palgrave Macmillan.

Falkner, Gerda. 2016. The EU's Current Crisis and Its Policy Effects: Research Design and Comparative Findings. Journal of European Integration 38 (3): 219-235.

Falkner, G., M. Hartlapp, S. Leiber, and O. Treib. 2004. Non-compliance with EU Directives in the Member States. Opposition Through the Backdoor? West European Politics 27 (3): 452-473.

Falkner, Gerda, O. Treib, and E. Holzleithner. 2008. Compliance in the Enlarged European Union. Living Rights or Dead Letters? Aldershot: Ashgate.

Fidesz. 2007. A Stronger Hungary. The Manifesto of Fidesz-Hungarian Civic Union. Abridged Version. http://static-old.fidesz.hu/download/_EN/Fidesz PP2007_EN.pdf. Accessed 11 November 2019. 
Goetz, K.H., and H. Wollmann. 2001. Governmentalizing Central Executives in Post-communist Europe: A Four-Country Comparison. Journal of European Public Policy 8 (6): 864-887.

Grabbe, Heather. 2003. Europeanization Goes East: Power and Uncertainty in the EU Accession Process. In The Politics of Europeanization, ed. K. Featherstone and C.M. Radaelli, 303-327. Oxford: Oxford University Press.

Grande, E., and S. Hutter. 2016. Introduction: European Integration and the Challenge of Politicisation. In Politicising Europe. Integration and Mass Politics, ed. S. Hutter, E. Grande, and H. Kriesi, 3-31. Cambridge: Cambridge University Press.

Hajnal, G., and S. Csengődi. 2014. When Crisis Hits Superman: Change and Stability of Political Control and Politicization in Hungary. Administrative Culture 15 (1): 39-57.

Halmai, Gábor. 2016. The Invalid Anti-migrant Referendum in Hungary. https://verfassungsblog.de/hungarys-anti-european-immigrationlaws/. Accessed 19 November 2019.

Hille, P., and C. Knill. 2016. 'It's the Bureaucracy, Stupid'. The implementation of the Acquis Communautaire in EU candidate countries, 1999-2003. European Union Politics 7 (4): 531-552.

Hooghe, L., and G. Marks. 2012. Politicization. In The Oxford Handbook of the European Union, ed. E. Jones, A. Menon, and S. Weatherill, 840-853. Oxford: Oxford University Press.

Hutter, S., and H. Kriesi. 2019. Politicizing Europe in Times of Crisis. Journal of European Public Policy 26 (7): 996-1017.

Immigration and Asylum Office. 2018. Statistics. http://www.bmbah.hu/index. php? option=com_k2 \&view=item\&layout=item\&id=492\&Itemid=1259\&lang. Accessed 20 November 2019.

Jelínková, Marie. 2019. A Refugee Crisis Without Refugees: Policy and Media Discourse on Refugees in the Czech Republic and Its Implications. Central European Journal of Public Policy 13 (1): 33-45.

Jobbik. 2018. For the People-Manifesto on Jobbik's Fundamental Principles for Government. https://www.jobbik.com/manifesto_on_the_guidelines_for_a_f uture_jobbik_led_government. Accessed 7 November 2019.

Knill, C., and J. Tosun. 2009. Post-accession Transposition of EU Law in the New Member States: A Cross-Country Comparison. European Integration Online Papers Special Issue 2 (13): 1-18.

Lavenex, Sandra. 1998. 'Passing the Buck': Europe Union Refugee Policies Towards Central and Eastern Europe. Journal of Refugee Studies 11 (2): $126-145$.

Lippert, B., G. Umbach, and W. Wessels. 2001. Europeanization of CEE Executives: EU Membership Negotiations as a Shaping Power. Journal of European Public Policy 8 (6): 980-1012. 
Magyar, Bálint. 2016. Post-Communist Mafia State: The Case of Hungary. Central European University Press. www.jstor.org/stable/10.7829/j.ctt19z 391g. Accessed 19 November 2019.

Meyer-Sahling, Jan-Hinrik. 2006. De-Politicisation Through the Backdoor? EU Integration, Administrative Reform and Party Patronage in East Central Europe. https://ecpr.eu/Filestore/PaperProposal/1f9dd72d-9f324143-9f55-df0f4dafdfcd.pdf. Accessed 6 April 2020.

Meyer-Sahling, Jan-Hinrik. 2011. The Durability of EU Civil Service Policy in Central and Eastern Europe After Accession. Governance: An International Journal of Policy, Administration, and Institutions 24 (2): 231-260.

Miciukiewicz, Konrad. 2011. Migration and Asylum in Central Eastern Europe: The Impacts of European Integration. In (Post)transformational Migration. Inequalities, Welfare State and Horizontal Mobility, ed. M. Nowak and M. Nowosielski, 177-200. Frankfurt/Main: Peter Lang.

MSZP. 2018. Tegyünk igazságot! MSZP választási program 2018. https:// mszp.hu/page/download? $\mathrm{ct}=\mathrm{doc} \& \mathrm{cid}=218 \& \mathrm{dt}=\mathrm{atch} \& \mathrm{did}=478$. Accessed 7 November 2019.

Nagy, Zsófia. 2019. Repertoires of Contention and New Media. The Case of a Hungarian Anti-billboard Campaign. East European Journal of Society and Politics 2 (4): 109-133.

Rauh, C., and M. Zürn. 2014. Zur Politisierung der EU in der Krise. In Krise der europäischen Vergesellschaftung? Soziologische Perspektiven, ed. Martin Heidenreich, 121-145. Wiesbaden: Springer VS.

Sedelmeier, Ulrich. 2008. After Conditionality: Post-accession Compliance with EU Law in East Central Europe. Journal of European Public Policy 15 (6): 806-825.

Sedelmeier, Ulrich. 2009. Post-accession Compliance with EU Gender Equality Legislation in post-communist New Member States. European Integration Online Papers 2 (13): 1-20.

Sedelmeier, Ulrich. 2011. Europeanisation in New Member and Candidate States. Living Reviews in European Governance 6 (1): 5-52.

Shevel, Oxana. 2011. Migration, Refugee Policy, and State Building in postcommunist Europe. Cambridge: Cambridge University Press.

Toshkov, Dimiter. 2012. Compliance with EU Law in Central and Eastern Europe. The Disaster that Didn't Happen (Yet). L'Europe en Formation 364 (2): 91-109.

Zhelyazkova, A., C. Kaya, and R. Schrama. 2017. Notified and Substantive Compliance with EU Law in Enlarged Europe: Evidence from Four Policy Areas. Journal of European Public Policy 24 (2): 216-238. 
Open Access This chapter is licensed under the terms of the Creative Commons Attribution 4.0 International License (http://creativecommons.org/licenses/ by/4.0/), which permits use, sharing, adaptation, distribution and reproduction in any medium or format, as long as you give appropriate credit to the original author(s) and the source, provide a link to the Creative Commons license and indicate if changes were made.

The images or other third party material in this chapter are included in the chapter's Creative Commons license, unless indicated otherwise in a credit line to the material. If material is not included in the chapter's Creative Commons license and your intended use is not permitted by statutory regulation or exceeds the permitted use, you will need to obtain permission directly from the copyright holder.

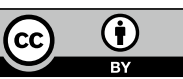

